\title{
CONCEPT GENIUS IN ITS HISTORICAL PERSPECTIVE
}

\author{
Irina Kolegaeva \\ Professor, Doctor of Philological Sciences, \\ Odesa I. I. Mechnikov National University, Ukraine \\ e-mail: irina_kolegaeva@ukr.net,orcid.org/0000-0002-5073-2184 \\ Lesia Strochenko \\ PhD, Assistant Professor, Odesa I. I. Mechnikov National University, Ukraine \\ e-mail: lesiastrochenko@gmail.com,orcid.org/0000-0003-3619-3484
}

\section{Summary}

The article is dedicated to the study of the English concept GENIUS in the historical perspective of its formation and functioning. The work outlines the main trends in philosophical studies of this phenomenon (irrational, rational, empirical, socio-cultural); analyzes the etymology and semantics of the English lexeme which nominates the given concept; offers the algorithm of the linguistic study of the conceptual field GENIUS. The first known instance of the term genius used in the English language is as far as the times of the Roman Empire, where it referred to a male spiritual protector or a guardian spirit. It was not until the Enlightenment when the connotations of the word obtained its present meaning referring to the superior or unique abilities of an individual. The second half of the XVIII century marks a turning point in the semantics of this lexical unit. Since then, genius has denoted not only a special ability, but also a person who has such quality. Nowadays the word genius and the corresponding concept have undergone a considerable extension of their meaning as a result of being overused, denoting people who have remarkable achievements in any possible sphere of human activity.

Keywords: conceptual field, etymology, extension of meaning, genius, phenomenon, semantics.

\section{DOI: https://doi.org/10.23856/3806}

\section{Introduction}

The given research aims at tracing the historical development of the concept GENIUS by outlining the main trends in philosophical studies of this phenomenon, analyzing the etymology and semantics of the English lexeme which nominates the concept, and working out the algorithm of the linguistic study of the conceptual field GENIUS.

The relevance of the article is determined by the fact that the phenomenon of genius as the highest manifestation of intellectual or creative activity of a person-genius has remained beyond the linguists' attention. However, there are numerous researches dedicated to the study of its philosophical, cultural and psychological aspects (Ball, 2014; Khomchenkova, 2007; McMohan, 2013; Simonton, 2020).

In his work "Divine fury: a history of genius", an acclaimed historian Darrin M. McMahon remarks that the starting point in the study of the phenomenon genius was in Ancient Greece: "It begins in classical Greece, when poets, philosophers, and statesmen first entertained the question of what makes the greatest men great, initiating a conversation that was continued by the Romans. What power did Socrates possess to make him the wisest of all men? What godlike force moved through Alexander or Julius Caesar as they leveled all before them? Why 
was the poet Homer able to sing like no other? What special something did these great-souled men possess? What special something possessed them?" (McMohan, 2013: 12).

Ball (2014) remarks, that in historical perspective, the term genius is rather problematic: it has had a long history of use, and has acquired multiple meanings, describing vastly different phenomena. The first known instance of the term genius used in the English language is during the Roman Empire, where and when it referred to a male spiritual protector or a guardian spirit. Usually, the protection offered by a genius was applied to individuals, families, and physical spaces. Every person, family, city, body of water, or other important physical structure had their own genius. In addition, a genius could also refer to the "spirit of the times" or zeitgeist. Over time, genius became more intimately connected with individuals. However, it was not until the Enlightenment that the connotations of the word obtained its present implications: genius started referring to the superior or unique abilities of an individual. In the second half of the XVIII century there happened a turning point in the semantics of this lexical unit (Ball, 2014). Since then, genius has denoted not only a special ability, but also a person who has such quality. That is when there appeared numerous researches, which gave impetus to further study of this phenomenon.

\section{The history of the philosophical aspect in studying the phenomenon of GENIUS}

Among numerous researches dedicated to the investigation of the philosophical aspects of the given phenomenon, Khomchenkova's thesis (2007) stands out, offering a detailed and reasonable classification of main trends in genius study.

The first one is irrational approach, which emphasizes the divine nature of genius and is closely related to archaic and religious ideas. The irrational view of the nature of genius correlates with the etymology of the word genius and can be traced in the dynamics of interpretation of this concept in language, culture and history. In Roman mythology, genius was a spirit, a deity, a guardian angel, who belonged to and was worshiped by every mail person throughout his life while Juno was a similar deity for a female. The views on creativity in medieval philosophy reflect the religious aura of the era, dictated by the ideology of the church. In the Middle Ages genius was most often identified with mental abnormalities and attributed to the intrigues of the dark forces. Therefore, geniuses were considered mentally ill, possessed by the devil, bewitched. If in the Middle Ages meticulous attention is focused mainly on religious and moral aspects, artistic and scientific creativity being of the secondary importance, the Renaissance is focused exactly on human creativity. In that era, the cult of genius as a creative individual arises. However, despite considerable progress in science, technology, and art, the nature of the genius's creativity continues being viewed irrationally. Genius is regarded as a free personality who seeks to occupy the position of god (Khomchenkova, 2007).

By the XIXth century, when the phenomenon of genius became the subject of study in various sciences (especially in psychology and genetics), a less radical idea of a genius, namely as the most remarkable creative human ability appeared. Thus, the rational approach was offered, within it genius was seen as the innate quality of a person, which stance enabled clarifying genius as a property of the human mind and made a start to study it in different directions of psychological and genetic research. This approach determined further investigations of biological (instincts, memory, genetic heredity and innate abilities in creativity) and psychological (fantasy, imagination, inspiration, and spontaneity) factors of genius (Khomchenkova, 2007). 
The next successive trend in the study of genius is empirical approach, according to which genius is the acquired property of a person in the process of his/her development. According to Simonton (2020), empirical research on genius as eminent achievement goes back almost two centuries. The first studies established the normal "bell-shaped" curve in the statistical treatment of human behavior. Later this concept of the normal distribution was applied to the so-called "natural ability", so that those at the upper tail of this distribution would inevitably attain distinction as either creators or leaders. Researches also argued that natural ability was in fact natural in the sense that it was strongly inherited and thus passed down through family pedigrees. Subsequent research showed that environmental factors, such as family background and education, play a major role in the emergence of genius. Basing on the above mentioned facts, Simonton concludes, that genius is both born and made (Simonton, 2020).

Rational and empirical trends mutually resulted in the new approach to the psychological study of the genius phenomenon. Definitions of genius in terms of intelligence quotient (IQ) are based on research originating in the early 1900s. In 1916 the American psychologist Lewis M. Terman set the IQ for "potential genius" at 140 and above, a level exhibited by about 1 in every 250 people. Leta Hollingworth, an American psychologist who studied the nature and nurture of genius, suggested an IQ of 180 as the threshold - a level that, at least theoretically, is exhibited by only about one in every two million people (Genius-c). The researches based on this definition of genius, namely, genius as a bearer of superlative IQ, are comparatively rare. According to Simonton (2020), that does not mean that investigators rarely use intelligence tests. On the contrary, those measures are among the most frequently used and best standardized instruments in psychology. The problem, rather, is that few inquiries even attempt to capture a single participant who scores at the genius level of, say, IQ 140. Consequently, investigators while adopting this definition have to use a special methodology to obtain a reasonable sample size for empirical research (Simonton, 2020).

The fourth approach to the study of genius is socio-cultural, which analyzes both significant and problematic interaction of a genius and society. On the one hand, genius is an innate quality, on the other - certain conditions for its formation and implementation are needed. Noteworthily, these factors are not exhaustive. The existence of genius is impossible without its recognition by the society. That makes genius predominantly a social phenomenon. The following main functions of genius phenomenon in the social context can be singled out, they being: educational, reformist, rebellious and prophetic (Khomchenkova, 2007).

According to McMohan (2013), the genius bridges the gap between people and the gods: "Geniuses pulled back the curtain of existence to reveal a universe that was richer, deeper, more extraordinary and terrible than previously imagined. The baffling beauty of space-time was no different in this respect from the sublime majesty of Byron's poetry, Beethoven's symphonies, or Poincaré's theorems, as radiant as an Edison light bulb or the explosion of the atomic bomb. Genius was a flash of light, but its brilliance served to illuminate the dark mystery that surrounded and set it apart" (McMohan, 2013: 150).

Summing up the outline of main approaches to the study of genius, we would quote the Encyclopcedia Britannica, a general knowledge English-language online encyclopedia: "The word genius is used in two closely related but somewhat different senses. In the first sense, as popularized by Terman, it refers to great intellectual ability as measured by performance on a standardized intelligence test. In the second and more popular sense, as derived from work of the 19th-century English scientist Sir Francis Galton, it designates creative ability of an exceptionally high order as demonstrated by actual achievement - always provided that such achievement is not merely of transitory value or the result of accident of birth" (Genius-c). 


\section{The etymology and semantics of the English lexeme genius}

Let us, first of all, consider the motivational features of the studied concept through the analysis of the etymology of the English lexical unit genius which comes from Latin. No doubt, the Roman genius, was very far from the modern "genius," conceived as an individual of exceptional creativity and insight (McMohan, 2013).

"Genius (n.) late 14 c., "tutelary or moral spirit" who guides and governs an individual through life, from Latin genius "guardian deity or spirit which watches over each person from birth; spirit, incarnation; wit, talent;" also "prophetic skill; the male spirit of a gens," originally "generative power" (or "inborn nature"), from PIE *gen(e)-yo-, from root *gene- "give birth, beget," with derivatives referring to procreation and familial and tribal groups. Sense of "characteristic disposition" of a person is from 1580s. Meaning "person of natural intelligence or talent" and that of "exalted natural mental ability" are first recorded 1640s" (Genius-a).

Thus, the inner form of this nomination foregrounds the irrational component of the corresponding concept.

Modern explanatory dictionaries of the English language register four sememes of the lexeme genius and offer the following definitions.

"Genius 1. A good or evil spirit, or demon, supposed by the ancients to preside over a man's destiny in life; a tutelary deity; a supernatural being; a spirit, good or bad. Cf. Jinnee "The unseen genius of the wood." We talk about the genius still, but with thought how changed! The genius of Augustus was a devotee of the demon, to be sworn by and to receive offerings on an altar as a god"(Genius-b).

So far, the first sememe refers to the genius-spirit, that affects (for the good or bad) the destiny of a person or locality, which testifies that, the original meaning of this lexical unit, rooted in Latin, is preserved up to now.

"Genius 2. A man endowed with uncommon vigor of mind; a man of superior intellectual faculties and creativity; Shakespeare was a rare one genius"(Genius-b).

The second sememe indicates a person with extraordinary abilities. These abilities relate to human intelligence or his/her creativeness. Such qualifiers as uncommon and superior emphasize the uniqueness of the intellectual and creative capabilities of a person.

"Genius 3. Distinguished mental superiority; uncommon intellectual power; especially, a superior power of invention or the generation of any kind, or of forming new combinations; as a man of genius. Genius of the highest kind implies an unusual intensity of the modifying power" (Genius-b).

The third sememe indicates this extraordinary ability, quality of a person. Once again, such semantic components (semes) as uncommon, superior and distinguished emphasize the novelty of the discovery or invention made by the corresponding person.

"Genius 4. The peculiar structure of mind with which each individual is endowed by nature; that disposition or aptitude of mind which is peculiar to each man, and which qualifies him for certain kinds of action or special success in any pursuit; special taste, inclination, or disposition; as, a genius for history, for poetry, or painting" (Genius-b).

Finally, the last sememe denotes the natural inclination of a person to a certain type of occupation - aptitude, disposition, which is inherent in every person and is an individual feature-peculiar to each man.

The fourth sememe in the structure of the lexical meaning of lexeme genius corresponds with the ideas of McMohan (2013), who claims that we live in the age when football coaches and rock stars are frequently described as "geniuses". The luster of the word - once reserved 
for a pantheon of eminence, the truly highest of the high - has no doubt faded over time, the result of inflated claims and general overuse. The title of a BBC television documentary on the life of the Nobel Prize-winning physicist Richard Feynman sums up the situation: "No Ordinary Genius." (McMohan, 2013: 348). "Genius is seemingly everywhere today, hailed in our newspapers and glossy magazines, extolled in our television profiles and Internet chatter. Replete with publicists, hash tags, and "buzz," genius is now consumed by a celebrity culture that draws few distinctions between a genius for fashion, a genius for business, and a genius for anything else...<> .. All might have their fifteen minutes of genius. All might be geniuses now" (McMohan, 2013: 350).

Thus, we draw the conclusion that the word genius and the corresponding concept have undergone extension of meaning as a result of overuse, denoting people who can achieve brilliant results in fact in any sphere of human activity.

\section{The algorithm of the linguistic study of the conceptual field GENIUS}

Language is one of the main tools of cognition and conceptualization of the world. To examine a concept through the language is one of the most reliable ways of linguistic analysis which allows to detect its conceptual features and to work out the model of the concept. The structure of a concept is manifested through dictionary definitions of the corresponding lexical units (the name of the concept and its synonyms) and through speech contexts. The study of the verbalized concept involves: (a) defining the linguistic means that objectify it, (b) the fullest possible description of the semantics of these units and (c) modeling the meaning of the concept as a holistic mental unit marked with its national originality. The main methods employed in our conceptual analysis were: (1) componential analysis, (2) etymological analysis, (3) identification of synonyms of the lexeme which names the corresponding concept and (4) the study of ways of conceptualization as secondary reinterpretation, for example in idioms and aphorisms.

Our observations of the empirical material led us to the following hypothesis. GENIUS is a conceptual field divided into three segments, each of which is denoted by a corresponding sub-concept:

1) GENIUS as a phenomenon;

2) GENIUS as a person;

3) A WORK OF GENIUS as a result of a genius' activity.

These segments have a nuclear-peripheral structure, the analysis of which is carried out on the language and speech material, which represents both naive and scientific versions of the picture of the world. These segments are connected within the conceptual field by a cyclic connection. Cyclization of the conceptual field GENIUS occurs when a person (2) endowed with the phenomenon of genius (1) creates a certain product (3) (depending on the field of his activity), which is recognized as genius. Only under such conditions the person (creator of this product) will be nominated a genius.

\section{Conclusion}

Among main trends in the study of the phenomenon of genius are: irrational approach, which emphasizes the divine nature of genius and is closely related to archaic and religious ideas; rational approach, within which genius is seen as the innate quality of a person, which makes it possible to clarify genius as a property of the human mind and to study it in different directions in psychology and genetics, as well as to determine biological (instincts, memory, 
genetic heredity and innate abilities to creativity) and psychological (fantasy, imagination, inspiration and spontaneity) factors of genius; empirical approach, according to which genius is the acquired property of a person in the process of his/her development; socio-cultural approach, which considers both significant and problematic interaction of a genius and society.

In the historical perspective, the word genius and the corresponding concept have undergone extension of meaning as a result of overuse, currently denoting people who can achieve good results in fact in any sphere of human activity.

The conceptual field GENIUS consisting of three segments as well as the relationship among them will be the subject of our further publications.

\section{References}

Ball, L.C. (2014). The genius in history: historiographic explorations. The Wiley handbook of genius. Oxford: Wiley Blackwell, 3-19.

Khomchenkova, E.A. (2007). Fenomenolohyya henyal'nosty: ot antropnoy $k$ sotsyokul'turnoy determynatsyy. [Phenomenology of genius: from anthropological to socio-cultural determination]. Candidate's thesis, Omsk. [In Russian]

McMohan, D.M. (2013). Divine Fury: a history of genius. New York: Basic Books.

Simonton, D.K. (2020). Genius. The Palgrave Encyclopedia of the Possible. London: Palgrave Macmillan, Cham, 1-6.

Genius-a. URL: https://www.etymonline.com/word/genius

Genius-b. URL: http://www.thefreedictionary.com/genius

Genius-c. URL: https://www.britannica.com/topic/genius-psychology 